\title{
Religious Situation in Contemporary Czech Society
}

\author{
David Václavík, Dana Hamplová, Zdeněk R. Nešpor
}

https://doi.org/10.14712/25704893.2018.6

\begin{abstract}
The study deals with the analysis of the religious situation in Czech society after 1989. The starting point is the analysis of the broader historical and sociopolitical context. The study itself examines an analysis of the key census data from 1991, 2001, and 2011, together with the results of research explicitly focused on the religion and religious behavior of the Czech population. These are mainly international studies, such as the EVS, ISSP or AUFBRUCH, and Czech research in the field of DIN. The study also includes an identification of topics and problems that have not yet been sufficiently explored in the context of studying the relationship between religion and contemporary Czech society.
\end{abstract}

Keywords: religion; modern Czech society; secularization; state; sociological data analysis

\begin{abstract}
Abstrakt: Studie se věnuje rozboru náboženské situace v české společnosti po roce 1989. Východiskem je rozbor širšího historického a sociopolitického kontextu. Samotná analýza se pak opírá o rozbor klíčových údajů z cenzů z let 1991, 2001 a 2011, které jsou doplněné o výsledky výzkumů zaměřených explicitně na náboženství a náboženské chování české populace. Jde především o mezinárodní výzkumy EVS, ISSP či AUFBRUCH a český výzkum DIN. Součástí studie je i identifikace témat a problémů, které zatím v souvislosti se studiem vztahu náboženství a současné české společnosti nebyly dostatečně zkoumány.
\end{abstract}

Klíčová slova: náboženství; moderní česká společnost; sekularizace; stát; sociologická analýza dat

Received: 1 June 2018, Accepted: 25 September 2018

Published online: 30 November 2018

doc. PhDr. David Václavík, Ph.D., Department for the Study of Religion, Faculty of Arts, Masaryk University; Department of Philosophy, Faculty of Sciences, Humanities and Education, Technical University of Liberec

E-mail:vaclav@phil.muni.cz; david.vaclavik@tul.cz prof. PhDr. Zdeněk Nešpor, Ph.D., Institute of Sociology, Czech Academy of Sciences E-mail: zdenek.nespor@soc.cas.cz prof. PhDr. Dana Hamplová, Ph.D., Institute of Sociology, Czech Academy of Sciences E-mail: dana.hamplova@soc.cas.cz

(C) 2017 The Authors. This is an open-access article distributed under the terms of the Creative Commons Attribution License (http://creativecommons.org/licenses/by/4.0). 


\section{(1) Introduction}

In a number of international comparative surveys, the Czech Republic has been steadily occupying a position among countries with the lowest levels of religiosity. ${ }^{1}$ Several sociological studies accentuate the fact that the secular profile of the Czech Republic is an exception even among post-Communist Central and Eastern European countries whose religious development has been strongly formed by an explicit anti-religious regime for almost half a century. ${ }^{2}$ Moreover, when comparing populations of the Czech and Slovak Republics, countries that formed one state for a significant part of the 20th century, one finds a curiously dramatic difference between their religious profiles. ${ }^{3}$ In this context it suffices to note that the Czech Republic represents a 'special case', comparable to that of Eastern Germany (former German Democratic Republic) or Estonia, which are commonly regarded as the most irreligious places in Europe. ${ }^{4}$

However, several studies have been published in the last few years that questioned the widely held assumption about the Czech society as one of the most atheist countries in present-day Europe. ${ }^{5}$ They maintain that this assumption is based on a lack

1 Dušan LužnÝ and Jolana Navrátilová, "Religion and Secularisation in the Czech Republic", Czech Sociological Review 9 (1, 2001), p. 85-98; ANDREW M. GREELEY, Religion in Europe at the End of the Second Millennium: A Sociological Profile, New Brunswick: Transaction Publishers 2003, passim; David Voas, "The Rise and Fall of Fuzzy Fidelity in Europe", European Sociological Review 25 (2, 2009), p. 155-168; Tом W. Sмiтн, "Beliefs about God across Time and Countries", in INSA BECHERT and MARKus QuANDT (eds.), ISSP Data Report: Religious Attitudes and Religious Change, Köln: GESIS 2013, p. 13-28.

2 Siniša ZrinšČAK, "Generations and Atheism: Patterns of Response to Communist Rule Among Different Generations and Countries", Social Compass 51 (2, 2004), p. 221-234; Olaf MüLler, "Secularization, Individualization, or (Re)vitalization?: The State and Development of Churchliness and Religiosity in Post-Communist Central and Eastern Europe", Religion and Society in Central and Eastern Europe 4 (1,2011), p. 21-37.

3 Greeley, Religion in Europe at the End of the Second Millennium, p. 130-131; PaUl Froese, "Secular Czechs and Devout Slovaks: Explaining Religious Differences", Review of Religious Research 46 (3, 2005), p. 269-83; cf. JAN VÁNĚ and MARTINA ŠTíPkovÁ, “The National Religious Environment and the Orthodoxy of Christian Beliefs: A Comparison of Austria, the Czech Republic and Slovakia”, Sociologický časopis / Czech Sociological Review 49 (3, 2013), p. 403-425.

4 Detlef Pollack, "The Change in Religion and Church in Eastern Germany After 1989: A Research Note", Sociology of Religion 63 (3, 2002), p. 373-87; Paul Froese and Steven Pfaff, "Explaining the Religious Anomaly: A Historical Analysis of Secularization in Eastern Germany", Journal for the Scientific Study of Religion 44 (4, 2005), p. 397-422; Monika WohlRaB-Sahr, "Forced' Secularity?: On the Appropriation of Repressive Secularization", Religion and Society in Central and Eastern Europe, 4 (1, 2011), p. 63-77; Aтко Remmel, "Ambiguous Atheism: The Impact of Political Changes on the Meaning and Reception of Atheism in Estonia", in Roberto Cipriani and Franco Garelli (eds.), Sociology of Atheism, Leiden: Brill 2016, p. 233-251.

5 Dana Hamplová and ZdeněK R. Nešpor, "Invisible Religion in a 'Non-believing' Country: The Case of the Czech Republic”, Social Compass 56 (4, 2009), p. 581-597; Olga NEŠPoroví and ZDENĚK R. Nešpor, "Religion: An Unsolved Problem for the Modern Czech Nation”, Sociologický časopis / Czech Sociological Review 45 (6, 2009), p. 1215-1237; ZDENĚK R. NEŠPOR, Přiliš slábi ve víre: Česká ne/religiozita v evropském kontextu [Too Weak in Faith: Czech Non/Religiosity in the European Context], Praha: Kalich 2010, passim; David VÁclavík, Náboženství a moderni česká společnost [Religion and the Modern Czech Society], Praha: Grada 2010, 243 p.,passim; DANA 
of understanding of the fact that Czech religiosity is characterized by high levels of privatization and individualization, as well as strong distrust in traditional religious institutions, especially in the mainstream Christian churches. These studies rely on data from empirical surveys and their authors emphasize that the individualized and privatized spirituality is often mistakenly interpreted as atheism. Based on data from a national survey Detraditionalization and Individualization of Religion (DIN 2006), Hamplová and Nešpor ${ }^{6}$ showed that despite low levels of membership in religious institutions and low participation in religious activities, Czechs are not indifferent toward religious and spiritual phenomena. A rather high level of 'religious illiteracy' is another important feature of the Czech religious landscape. ${ }^{7}$

\section{(2) Historical indication/examination}

To correctly understand the complicated and ambiguous attitudes of the Czech population toward religion, one needs to consider several political, social, and demographic developments in the 20th century. A specifically Czech attitude toward religion and religious institutions was visible as early as in the period of the so-called First Czechoslovak Republic (1918-1938). This period was characterized by a rising distrust towards religious institutions, a tendency for privatization of religions and a growing indifference towards religion. This religious transformation was dominated by the efforts to distance oneself from the dominant Catholic Church. The most dramatic changes took place in the first years of the independent Czechoslovak state's existence, i.e. approximately until $1925 .^{8}$ The comparison of the data from the 1910 and the 1921 Censuses shows that the Roman Catholic Church lost more than 1.2 million members in this period. This decline, however, affected different regions and ethnic groups to a different extent. Its decline was most profound in Bohemia (the Western part of the country), less so in Moravia and Silesia. The 'renegades' were mostly of Czech nationality and the number of Czech (Sudeten) Germans who have left the Church was small.

After World War II, the above-described tendencies were strengthened by two factors: deportation of the German minority from the Czech borderlands in the years 1945-1947 (approximately 2.6 million individuals were affected) and the establishment of Communist rule in 1948. As a consequence of the deportations, the country lost a significant proportion of its Catholic population. However, the deportations also profoundly influenced other denominations (German Evangelical Churches, New Apostles Church and Old Catholic Church). The demographic and socio-eco-

Hamplová, Náboženství v české společnosti na prahu 3. tisíciletí [Religion and the Czech Society on the Threshold of the Third Millennium], Praha: Karolinum 2013, passim.

6 Hamplová and NešPor, “Invisible Religion in a 'Non-believing' Country”, p. 594.

Comp. f.g. Stephen Protero, Religious Literacy, New York: HarperOne 2008, passim.

8 Comp. Cynthia J. Paces, “'The Czech Nation Must be Catholic!': An Alternative Version of Czech Nationalism During the First Republic," 1999 
nomic changes brought on by the removal of German population were even more serious. The formerly German regions (the so-called Sudetenland) were essentially depopulated. The resettlement of these borderland areas was centrally organized ${ }^{9}$ but $^{-}$ the strategy was to send in individuals, not communities, as was the case of Silesia in Poland. The settlers were often recruited from the supporters of the political Left, from lower social classes and groups with poor education. In particular, 'politically reliable' sympathizers of the Communist Party were often selected for the task. As a consequence, there was a higher proportion of individuals 'without any religious affiliation' arriving to the borderlands..$^{10}$ This manner of re-settlement of the areas previously inhabited by Germans created a discontinuity of family and community ties and contributed to the disintegration of local religious memory. However, we ought to mention that there were some exceptions, such as settlements by re-immigrants from Eastern Europe (e.g. communities of ethnic Czechs from Volhynia). They predominantly belonged to the Orthodox Church and greatly contributed to its transformation after World War II.

After 1948, when the Communist regime was established in Czechoslovakia, the social, demographic and cultural transformation of Czech society continued. This development also included a rapid decline of participation in religious activities. Even though the downturn started in the late 1940s, the most profound transformation occurred only in the 1960s and again in the mid-1970s. However, it is necessary to emphasize that the Communist regime did not come with a distinctively new attitude towards religion. It skillfully used pre-existing tendencies (e.g. anticlericalism of intellectuals). Thus, in the Czech case, the classical Marxist interpretation of religion built on and drew its credibility from nationalist anti-Catholicism of the pre-WWII period. However, the anti-religious ethos did not radically transform the Czechs' attitudes to religion. It only further deepened the distrust towards religious institutions, strengthened indifference towards religion, and successfully contributed to 'religious illiteracy'. It did not produce a conscious acceptance of atheism in Czech society. ${ }^{11}$

Nevertheless, the gradually increasing indifference towards religion had rather ambiguous consequences. On one hand, the role of religion in everyday life was weakened. On the other hand, religion was regarded as something 'clandestine', encompassing both protest and an alternative. However, the newly gained attractive-

\footnotetext{
${ }^{9}$ Historically speaking, it would be appropriate to distinguish between a so-called wild resettlement and a 'spontaneous' inhabiting of the borderlands related to it, which happened in the first months after the war, and the later, organized depopulation of the areas.

${ }^{10}$ The strategy of the Communist Party was carefully 'phased'. In the years following the war, it relied on a form of cooperation with some religious groups, e.g. the Czechoslovak Church. The Communist Party then advocated a cooperation with churches; recruitments for the Czechoslovak Hussite Church even took place in the borderlands (with respect to the Church because of the property of German Evangelical Church in Bohemia, Moravia, and Silesia; with respect to the Party due to a proclaimed anti-clericalism). After 1948, however, this kind of 'cooperation' ceased to be of interest to the Communist Party.

${ }^{11}$ Given the available data, the rate of the so-called analytical atheism (i.e. a conscious rejection of whatever kind of supernatural based on relatively clearly formulated reasons) in Czech society is spread as widely as in other countries of Western and Northern Europe.
} 
ness did not mean that religion started to exert more influence on everyday life. This fact emerged fully in 1968 when the Communist rule lost its last bits of legitimacy in the eyes of absolute majority of population. In the 1970s and 1980s, the religious organizations, particularly the Catholic Church, but in some respect the religion itself, gradually became a symbol of dissent and hope. Yet, this protest and hope was political rather than an expression of a spiritual search for a new life. The everyday life was more and more enmeshed in consumerism and individualized materialism.

\section{(3) The religious situation in Czech society after 1989 in census data}

The first relevant information regarding Czech religiosity after the collapse of the Communist regime in November 1989 was provided by the 1991 Census. Yet, its results need to be interpreted with the utmost caution since they reflect a specific situation of the early 1990s, strongly echoing recent political developments.

Based on the 1991 census, $44 \%$ of population declared a religious affiliation, whereas slightly less than $40 \%$ said they did not have any. The remaining $16 \%$ refused to answer the question. The Czech Statistical Office explains this relatively high figure by the fact that this information was not asked in previous years and even in the 1991 census, the answer was voluntary. ${ }^{12}$ The religious plurality typical for the late $1990 \mathrm{~s}$ was only emerging in the 1991 census and the Roman Catholic Church was clearly the strongest religious institution, accounting for $39 \%$ of the population. Some representatives of the Church interpreted this result as evidence of the Catholic 'character' of the Czech nation and as a promise for the future. Nevertheless, it was based on incorrect interpretation of the data or more accurately, it was a consequence of an inadequate expectation based on the euphoria of the 'post-revolutionary society'. Nevertheless, despite its limitations, the first post-Communist census highlighted some principal features of 'Czech religiosity'. In particular, it demonstrated important regional differences along two main axes: a) the 'traditional' axis of West-East (Bohemia and Moravia), which had already been noticeable before 1948; and b) the borderlands-inland axis, which is clearly a consequence of the sociodemographic changes after 1945. These regional differences - as many other surveys have shown apply not only to the levels of traditional church religiosity, which is markedly lower in the Czech borderlands. They also apply to non-traditional and alternative religious groups. ${ }^{13}$

12 The respondents had the option, for various reasons, to simply skip the question. Another possible reason could have been the fact that even before the census there had been an upsurge of disputes over whether to include the question on religious affiliation into the questionnaire. The annulment of a law prohibiting the question caused protests from some citizens, who may then have refused to answer the question. One also needs to take into consideration the option that some respondents refused to align their faith with a specific traditional church or religious group, and hence opted for this answer.

${ }^{13}$ Comp. to e.g. VÁClavík, Náboženství a moderní česká společnost, p. $135 \mathrm{f}$. 
The data from the 2001 census showed a completely different and more realistic picture of the Czech religious landscape. However, it needs to be emphasized that every census since 1991 has used a different measure of religiosity. Thus, it is necessary to treat the results with some caution and confront them with data from specialized surveys.

Nevertheless, in the 2001 census, the share of people belonging to any religion dropped by more than $10 \%$, whereas the proportion of those 'without any religious affiliation' increased by $20 \%$. Interestingly, the number of refusals also dropped by nearly a half. It is possible that at the beginning of the third millennium, the question of religion and its perception became a relevant part of life in Czech society. Overall, the second post-Communist census confirmed the trends that had been predicted by some surveys and demonstrated the weakening position of mainstream religious denominations.

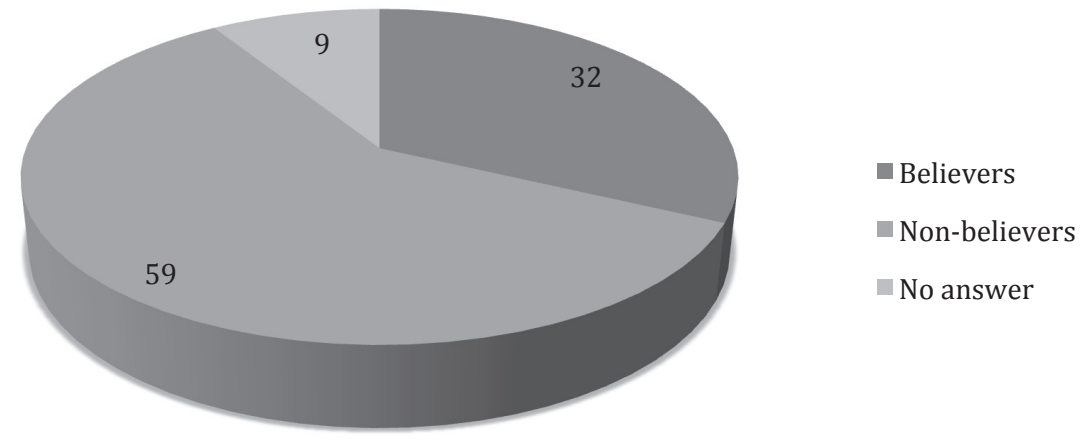

Figure 1: Religious affiliation according to the census in 2001 (in \%).

During the 1990s, mainstream churches lost a significant proportion of their memberships for several reasons. First, they were affected by demographic changes, particularly aging and mortality. Moreover, they were not able to address potential converts effectively. Some of them were also closely connected to specific cultural, regional, or historical circumstances related to their emergence or activities, which were obscure for contemporary believers, or else there may have been internal discrepancies leading to separation.

This development was most striking in the case of the Silesian Evangelical Church of Augsburg Confession that dwindled to only $42 \%$ of its former membership between 1991 and 2001. Furthermore, the Czechoslovak Hussite Church lost 44\% of its members, the Evangelical Church of Czech Brethren dropped by $43 \%$, as well as the Roman Catholic Church, which experienced a decline of $32 \% .{ }^{14}$ Such decline did

${ }^{14}$ In terms of absolute numbers, however, the greatest loss affected the Catholic Church $(1,280,605$ members) and the Evangelical Church of Czech Brethren (86,784 members). 
not, however, affect all religious groups. On the contrary: a number of them experienced an expansion. This was true especially for small evangelical denominations, particularly those influenced by the Pentecostal and charismatic movements. This shift reflects similar developments in many West European counties. ${ }^{15}$

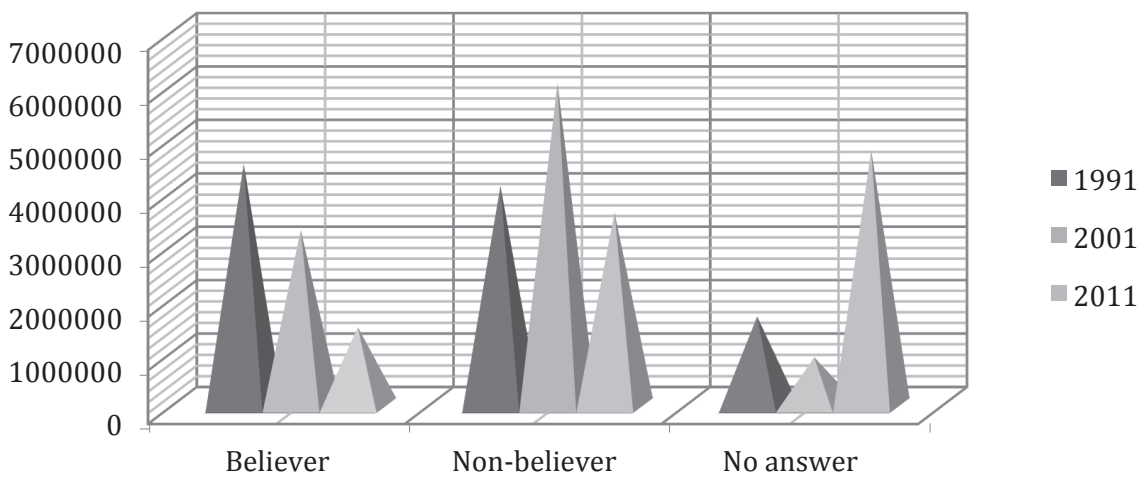

Figure 2: Religious affiliation in Czech society according to the censuses in 1991, 2001 and 2011.

The 2001 census showed that the regional differences had become even deeper than before. However, the decline of membership in traditional Christian denominations, especially the Roman Catholic Church, was proportional and did not selectively affect only specific regions. A comparatively highest number of Catholics still remained in southern Moravia, while their numbers were the lowest in northern and north-western Bohemia, as was the case in the early 1990s. ${ }^{16}$ Nevertheless, the relatively weak position of the traditional religious institutions in the regions previously populated by Germans does not mean that these places are a 'spiritual desert'. For small and alternative groups, Christian and non-Christian alike, these regions constitute a relatively promising area. In contrast to traditional religious groups that have suffered a considerable loss of members, small and alternative groups have been relatively successfully taking roots here..$^{17}$

${ }^{15}$ Comp. Alister E. McGrath, The Future of Christianity, Oxford: Oxford University Press 2002, passim.

${ }^{16}$ It is nonetheless interesting that while in 1991 Roman Catholics accounted for the majority of the entire populace in 22 district, in 2001 this was true only for three of them (Uherské Hradiště, Opava and Hodonín).

17 This growing religious plurality is further emphasized by the fact that, according to the 2001 census, the county of Liberec was home to 27,800 worshippers and 4,650 (16\%) of these were sympathizers of small and in our environment non-traditional religious groups, whose majority we can define as the so-called new religious movements. A similar occurrence can be observed in other district in northern Bohemia: in the district of Jablonec nad Nisou it was $16.6 \%$, in the Ústí nad Labem district $16 \%$ and in the Most district $15.2 \%$. By contrast, in districts where traditional religious groups had a strong position, such as in Moravian districts, the proportion of non-traditional religious groups did not reach 10 percent: in Zlín district 6\% registered as supporters of small and 
The last census from 2011 demonstrated another radical shift away from traditional religious groups, with growing indifference or even apathy towards religion. However, similarly to previous censuses, one needs to consider the data with some caution. In contrast to the previous data collections, the question about religious affiliation was explicitly marked as voluntary. Partly as a consequence, only $14 \%$ of Czechs adhered to a specific religious group or denomination, while 7\% said they were believers without belonging to any denomination or a religious group. Another $34 \%$ proclaimed themselves as non-religious. In total, $45 \%$ of the population refused to answer the question. Thus, in comparison with 2001, the decline affected not only those who explicitly declared a religious affiliation (dropping from $32 \%$ to less than $21 \%$ ) but also those who said they were not religious (dropping from $59 \%$ to $35 \%$ ). Moreover, the number of individuals refusing to answer rose dramatically (from $9 \%$ to $45 \%)$.

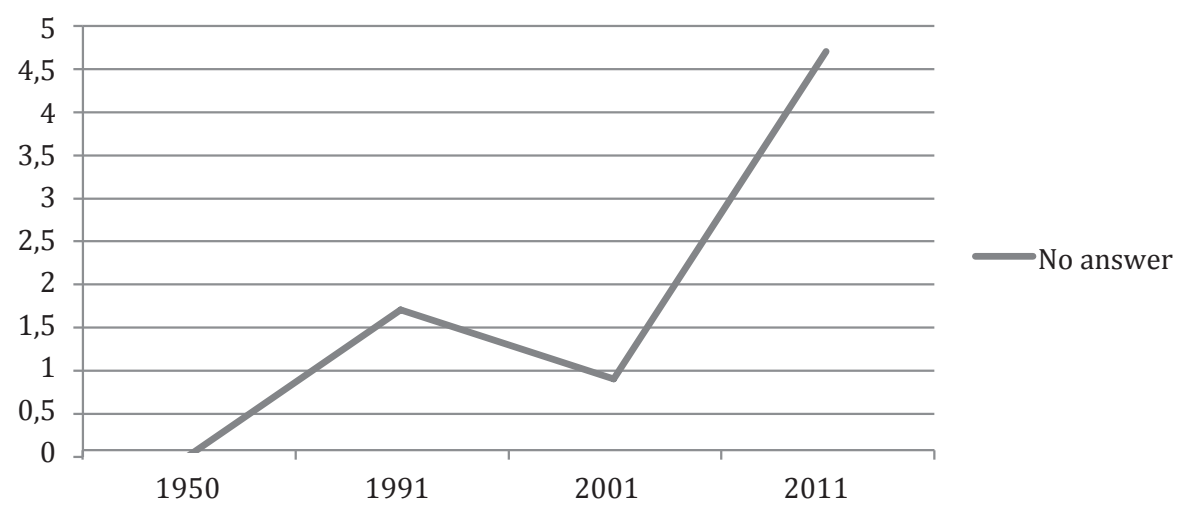

Figure 3: Growth in the "category" no answer between 1950 and 2011. ${ }^{18}$

It is clear that these changes cannot be interpreted using the census data. A more detailed survey would be necessary to see whether this development indicates increasing religious indifference. It is also possible that the question about religious/ non-religious identity lost its meaning. ${ }^{19}$ Yet there are other potential explanations. Some religious groups might have refused to answer the question for dogmatic reasons. For example, the leadership of The Church of Jesus Christ of Latter-day Saints

non-traditional religious groups, in Hodonín district their numbers reached 4.2\% and in Ždár nad Sázavou district $4.5 \%$.

${ }^{18}$ The answer on religious affiliation was obligatory in the census in 1950 and even in 1991 (but during this census, it was not strictly required). It has been facultative since 2001.

${ }^{19}$ In 2011, persons not stating their relationship to faith (not marking they were either religious or without creed) but who wrote they were atheists, were not included in the basic structure of population. The number of such persons was 1058; 698 men and 360 women. This number, however, only accounts for those who remembered and noted it down; such possibility was not offered in the manual. 
that recommends its member not to fill in the answer adopted such strategy. Similar reasons can be assumed in case of some members of established churches.

Additional data related to regional differences or sociodemographic indicators confirm the already known trends. The last census demonstrated a further weakening of traditional religious groups on one hand, and strengthening of 'small' Christian evangelical groups (e.g. Brethren Church, Apostle Church), alternative religious communities, and other non-traditional groups (e.g. individuals declaring themselves as Buddhist ${ }^{20}$ ). In contrast to the previous censuses, respondents were offered an option "believer without religious affiliation". If we also add to this group those who declared themselves as Catholic or Christian but did not specify any church or Christian denomination, the size is by no means negligible. It includes nearly 800 thousands individuals.

Table 1: Changes in membership in chosen religious groups between 1991 and 2011.

\begin{tabular}{l|l|l|l}
\hline & $\mathbf{1 9 9 1}$ & $\mathbf{2 0 0 1}$ & $\mathbf{2 0 1 1}$ \\
\hline Catholic Church & $4,021,385$ & $2,740,780$ & $1,083,899$ \\
\hline Czech Brethren Evangelic Church & 203,996 & 117,212 & 51,936 \\
\hline Czechoslovak Hussite Church & 178,036 & 99,103 & 39,276 \\
\hline Jehovah's Witnesses & 14,575 & 23,162 & 13,097 \\
\hline Orthodox Church in Czech Lands & 19,354 & 22,968 & 20,628 \\
\hline Silesian Evangelic Church of Augsburg Confession & 33,130 & 14,020 & 8,162 \\
\hline Brethren Church & 2,759 & 9,931 & 10,872 \\
\hline Seventh Day Adventists & 7,674 & 9,757 & 7,394 \\
\hline Greek Catholic Church & 7,030 & 7,675 & 9,927 \\
\hline Christian bodies & 3,017 & 6,927 & 3,458 \\
\hline Apostolic Church & 1,485 & 4,565 & 4,934 \\
\hline Brethren Unity of Baptists & 2,544 & 3,622 & 3,208 \\
\hline Methodist Evangelic Church & 2,855, & 2,694 & 1,952 \\
\hline Old-Catholic Church & 2,725 & 1,515 & 1,736 \\
\hline Federation of the Jewish Communities in the Czech Rep. & 1,292 & 1,515 & 1,132 \\
\hline Neo-Apostolic Church & 427 & 449 & 98 \\
\hline
\end{tabular}

The census data do not provide any information about the trust in religious institutions or churches. However, it is an important issue if we want to understand the public role of religion in modern Czech society. The degree of trust in religious institutions is regularly asked for, together with the degree of trust in other key social institutions (political bodies, courts, army, education system etc.). Based on accessible data, it becomes clear that after a few years in the early 1990s when religious institutions enjoyed a rather satisfying amount of trust of their followers (over 50\%),

${ }^{20}$ The strongest group was Diamond Way Buddhism - Karma Kagyu Lineage claiming 3,484 followers in the census. 
in the late 1990s at the latest, this declined significantly and today, religious organizations account for one of the least trustworthy public institutions in Czech society.

The Czechs are keen to negatively perceive any kind of occurrence that can be interpreted as an attempt by churches or religious organizations to influence public affairs. It is then irrelevant if these occurrences relate to potential political declarations or the opportunity to influence economic developments. The lowest level of trust, however, has certainly been affected by disputes over restitutions of church property.

\section{(4) Trends and transformation of "Czech religiosity" as seen by quantitative surveys from the start of the new millennium}

As repeatedly stated above, the census data must be treated very carefully. It is better to view them as "illustrative" only, or as signals of certain trends, e.g. the decrease of the number of members of traditional religious institutions involving a certain de-institutionalisation of Czech religiosity. However, to adequately analyse these trends, we need to use data from more specific surveys. The vast majority of these took place before 2011 and cannot therefore help much to clarify questions raised by the last population census.

Still, their results bring numerous valuable pieces of information. We can use them to explain some trends in Czech religiosity at the turn of the millennium. The changing position of institutionalized religiosity is one of these trends. Almost all relevant surveys conducted in the 1990s, just like the few realized after 2000 have unequivocally demonstrated that this kind of religiosity underwent a relatively important decline in the 1990s. Of course, the question is how to interpret such decline. One possibility is to see it as the consequence of the long-term Czech distrust towards religious institutions, which may be tracked as far as to the end of the 19th century. In line with this explanation, the majority of Czechs seem to identify the Roman Catholic Church with religion in general. This means that the attitudes towards the Church reflect the overall stance to religious institutions. The relatively high degree of trust in churches in the early 1990s, as well as the relatively high percentage of people declaring support for a specific religious group, were clearly consequences of the exceptional situation given by specific circumstances of the transforming post-Communist society.

From as early as 1993, there were some signs of de-institutionalization of religious life. This may have been seen as returning secularization of Czech society - if we understand secularization as progressive marginalization of traditional religious institutions accompanied by an increase of religious plurality. However, it would be more precise to say that after the mid-1990s the Czech society started to experience demonopolization and deinstitutionalization of religious life. As a consequence, a spiritual marketplace has developed ${ }^{21}$ where the concept of believing without belonging de-

${ }^{21}$ Comp. WAde Clark Roof, Spiritual Marketplace: Baby Boomers and the Remaking of American Religion, Princeton: Princeton University Press 1999. 
veloped by the British sociologist of religion Grace Davie has become increasingly relevant. $^{22}$

In this respect, information on practices linked to traditional forms of institutionalized religiosity is of key importance. Past surveys dealt mainly with participation in regular religious rites and key life rituals (e.g. baptism, weddings, funerals). As far as taking part in regular religious practices (at least once a month) is concerned, all available survey data show it is rather low even compared to most ex-Soviet bloc countries, reaching some 7\%. Compared to the situation in the early 1990 s and the first years of the new millennium, the decline is clear, but not dramatic. However, if we consider longer-term trends, the situation seems to be relatively stable. Other religious practices (e.g. baptism) are also relatively insignificant. According to the surveys, only $1 / 3$ of respondents considered baptism to be important. However, this does not mean that religious acts, like baptism or religious wedding, are not interesting or even popular for a subgroup of the population. Being "interesting", however, means that some individuals consider them to be an alternative to ordinary secular ceremonies. They are viewed as something that brings a kind of "invigoration". Another explanation could be found in Grace Davie's concept of vicarious religion and its functions.

Aside from the information about the changing role of religious institutions, the respondents' personal attitudes towards religion are also important. According to the AUFBRUCH 2007 survey, only $23 \%$ of respondents claimed being religious, while $65 \%$ declared themselves as not religious. Another $11 \%$ considered themselves as neither religious nor irreligious. These results may be interpreted as another piece of evidence about the deepening secularization of Czech society. However, this interpretation is put into doubt if we compare the AUFBRUCH 2007 survey with data from the DIN 2006 survey. The latter survey provides a somewhat different view of this issue, as more than $50 \%$ of respondents claimed to be spiritual and more than $20 \%$ were unable to state whether they were spiritual or not. ${ }^{23}$

The weakening of traditional institutionalized religiosity or self-reflection of one's own religiosity are not the only important issues. We also need to consider the role and transformation of the religious, as well as the acceptance of certain spiritual and religious practices. The two key surveys conducted in the first decade of the new millennium, such as the DIN 2006 survey, the AUFBRUCH 2007 focusing on religiosity in Central and Eastern European countries, as well as large comparative surveys (ISSP and EVS), showed that a large proportion of the Czech population (40 to 50\%) believes in a certain form of transcendence. At the same time, the surveys showed that religious views have become greatly differentiated. Only a relatively small part of respondents (around 10\%) identified with a traditional Christian idea of a personal

${ }^{22}$ GRACE DAVIE, “Believing without Belonging: Is This the Future of Religion in Britain?”, Social Compass 37 (4, 1990), p. 455-469.

${ }^{23}$ Respondents were to comment on four specific characteristics of their own religiosity: (1.) I am spiritual and live according to religious teachings. (2.) I am spiritual in a certain way. (3.) I cannot say if I am spiritual or not. (4.) I am not spiritual and I am not interested in these things. 
God. Respondents were much more inclined to believe that God is a supernatural force, a form of spirit or life energy. Even a significant portion of those who declared as Christians adopted these ideas. ${ }^{24}$

Table 2: Belief in God and stability of belief (in \%), ISPP 2008.

\begin{tabular}{l|l}
\hline Belief in God & $\mathbf{\%}$ \\
\hline I don't belief in God & 40.3 \\
\hline I don't know if God exists and I don't believe if it is possible to find out & 14.8 \\
\hline I don't believe in personal God, but believe in some Higher Power & 16.3 \\
\hline Sometimes I believe, sometimes not & 6.9 \\
\hline Although I doubt about His existence, I believe in God & 10.5 \\
\hline God really exists and I don't doubt about it & 11.3 \\
\hline Total & $\mathbf{1 0 0 . 0}$ \\
\hline Stability of belief in God & $\mathbf{\%}$ \\
\hline I don't believe in God and I have never believed in God & 60.4 \\
\hline I don't believe in God, but I believed in God earlier & 11.4 \\
\hline I believe in God, but I didn't believe earlier & 4.9 \\
\hline I believe in God and I have always believed in God & 23.3 \\
\hline Total & $\mathbf{1 0 0 . 0}$ \\
\hline
\end{tabular}

Thus, this data demonstrates the plasticity and multifaceted character of Czech religiosity in the beginning of the new millennium. "Religious belief" - if we use a simplified term - is going more and more in the direction of what the British sociologist Paul Heelas calls spirituality. ${ }^{25}$ This term refers to a deinstutionalized form of religiosity, characterized by a strong tendency to syncretize and detraditionalize religious views. Its goal is individual development and consumption; religion is not a goal, but rather an instrument. It is not surprising that in the given context, transcendence takes the form of something more "in accordance" with other discourses and narrations in the pluralistic late-modern identity.

This trend is confirmed by other data concerning individual religious beliefs. Relatively low importance is assigned to traditional religious ideas linked to institutionalized religiosity, e.g. the belief in heaven, hell or resurrection. Less than $30 \%$ of respondents identified with these in the surveys (DIN 2006, AUFBRUCH 2007, ISSP 2009). On the other hand, things such as healing powers of amulets, the ability to foresee future or reliability of horoscopes are acceptable for more than $40 \%$ of

${ }^{24}$ Specific results were somewhat different, which resulted from different perception of the options given to the respondents. While, e.g. the AUFBR 2007 survey offered only the option I do not believe in God as a person but I do believe in a higher power (16\%), the DIN 2006 survey used two variants: (1.) There is some form of spirit or life power and (2.) There is a supernatural power. More than $40 \%$ of respondents chose one of these variants.

${ }^{25}$ Cf. Paul Heelas, Linda Woodhead, et al., The Spiritual Revolution: Why Religion Is Giving Way to Spirituality, Oxford: Blackwell 2005, passim. 
respondents. In some cases (e.g. the ability to foresee future) the positive answers exceeded $50 \%$. Once again it is true that ideas corresponding to the subjective spirituality of a late-modern consumer get more and more attention. It is irrelevant whether the "believer" claims to be a Christian, Buddhist or Neo-pagan. Obviously, this does not mean that this is the only "viable" form of religiosity in Czech society. Next to this one, there are other, relatively influential options. For example, these may include evangelical groups in Christian churches and denominations, which seem to be more successful and attractive than traditional Christianity even in the Czech context.

Table 3: Acceptance of religious ideas (in \%), DIN 2006.

\begin{tabular}{l|l|l|l|l|l}
\hline & \multicolumn{2}{l}{ Yes } & \multicolumn{2}{l}{ No } & \multirow{2}{*}{ Total } \\
\hline & definitely & probably & probably & definitely & \multirow{2}{*}{} \\
\hline Afterlife & 11.9 & 24.2 & 26.4 & 37.5 & 100.0 \\
\hline Heaven & 10.2 & 16.0 & 49.3 & 24.5 & 100.0 \\
\hline Hell & 8.3 & 13.2 & 24.8 & 53.7 & 100.0 \\
\hline Miracles & 8.4 & 18.6 & 26.1 & 46.8 & 100.0 \\
\hline Amulets & 5.6 & 37.0 & 27.0 & 30.3 & 100.0 \\
\hline Stars & 9.6 & 36.5 & 26.3 & 27.6 & 100.0 \\
\hline Fortunetellers & 10.8 & 42.2 & 24.0 & 23.0 & 100.0 \\
\hline Healers & 9.3 & 31.8 & 25.3 & 33.6 & 100.0 \\
\hline
\end{tabular}

It is clear that many representatives of traditional religious groups, as well as supporters of the "non-religious" approach will interpret this development as something that jeopardizes or degrades religion. Nevertheless, from the point of view of viability of religion in the following years, this tendency will probably be only marginal. The principal role is likely to be played by religious experience and the ability of individual religious groups and currents to offer an acceptable and sufficiently attractive alternative to the increasingly chaotic, less comprehensible, and thus more dangerous, technically depersonalized (post)modern society.

One must interpret the traditional "Czech atheism" in this context. There is no space for deeper analysis but let us say the following. The group that can be called analytic atheists is small and its size is close to the average of Western European countries. Yet, except for this group, the idea of "Czech atheists" usually helps to "hide" other phenomena, such as religious apatheism or individualized religiosity which are very common in Czech society.

\section{(5) Conclusions}

Surveys from the last two decades allow us to formulate conclusions concerning the relationship of Czech society to religion. They are crucial for understanding Czech religiosity: 
1. "Czech atheism" is not atheism. Most of the relevant survey data shows that truly atheistic attitudes are held only by a small minority of people. "Czech atheism" tends to be confused with other religious phenomena, such as deinstitutionalized religiosity and apathy towards religion (religious apatheism).

2. Low level of institutionalization of religious life. The attitudes of the Czech public towards religious institutions, particularly traditional churches, tend to be negative or indifferent at the very best. However, even those who are willing to explicitly declare affiliation to a specific religious group often do not participate in its "religious life". Such tendencies seem to be more obvious in case of the Roman Catholic Church and mainstream non-Catholic denominations (Evangelical Church of Czech Brethen, Czechoslovak Hussite Church).

3. Deep individualization of religion. These tendencies of Czech religiosity are in line with its significant individualization. It is reflected in both the ambivalent attitude to religious institutions and the high levels of religious syncretism.

4. Low level of commitment. One of the most obvious aspects of the high level of individualization of religion is its relatively ambivalent position in daily life. Commitment to religious practices is low and religious ideas and values exert only a small influence on other attitudes and behaviours.

\section{(6) Blank spaces}

Religion-related surveys provide us with relatively large datasets that may be used to analyse the form and tendencies of current Czech religiosity. However, we are still confronted with several gaps in the current scholarship when trying to compile a sufficiently representative "map of the current Czech religion". The following five clusters of issues are considered to be of the greatest importance and we believe they deserve appropriate attention.

1. Study of religious communities. Available data provide a certain picture of the macro-level of religious life. These are often used to formulate unfounded generalizations. Aside from this, the bits of information concerning this very layer do not allow us to adequately study the dynamics of activities of specific religious groups.

2. Study of compactness, differentiation and distribution of power of individual religious groups. Ideas of compact operation of individual churches and religious movements or even traditions tend to provide gross misinterpretation of available data. It shows that partial surveys focused on specific churches and movements will have to significantly deal with the internal dynamics and differentiation thereof.

3. Commitment to religious activity. Most surveys claim that one of the key problems of "Czech religiosity" is the low level of commitment. Yet no survey deals with this phenomenon to a sufficient level and this is why the analyses and interpretations thereof lack depth and relevance

4. Study of key strategies of religious groups. The vast majority of surveys ignore the fact that religious groups have their own strategies, which determine their activities. 
The study of such strategies would not only allow for a better understanding of motives underlying the behaviour of specific groups, but also the discrepancies among the expectations of their members or surrounding society in daily reality.

5. Study of Czech atheism. Even though the cliché of a high level of atheism in Czech society appears in almost all depictions of the Czechs' relationship to religion, this phenomenon appears to lack deeper examination. Most available studies tend to acquire historic or theoretical works and do not reflect the current scholarly debate focusing on the topics of unbelief and non-religion. They also rarely use empirical data.

\section{(7) Appendix: Studies of religion in the Czech Republic (Czechoslovakia) after 1989}

While the Communist government decree of 25 July 1954, following after freedom of confession was declared in the Constitution, banned state institutions from inquiring into the population's religious faith and from maintaining relevant registers, this does not imply no sociological and other religiosity-related survey took place under the Communist regime. The design, methodology and results were generally influenced by the prominent anti-religious ideology and the acquired data or the interpretations thereof were not available to public. ${ }^{26}$ Ideologically unbiased surveys started to appear only after 1989, while at the same time the academic and public discussion focused on the results was open; as for most of these, financed from public sources, primary data are available (cf. Váně 2012). The elementary overview may be divided to (a) representative quantitative studies, (b) qualitative studies and (c) historical-sociological studies.

Other than that, it is vital to mention census data (1991, 2001 and 2011), including religious belief declared by the population; this question was voluntary in the census, while in the last one, $45 \%$ people did not answer. Another problem is the changing census method; the differing interpretations of and answers to this only question focusing on religiosity; and the unavailability (incomplete availability) of primary data caused by personal data protection imposed by law. However, it is vital to note that the 2011 census allowed the respondents, aside from declaring membership in a church or explicit refusal thereof, to declare themselves as believers without any church membership. This was the option more than 700 thousand of Czechs ( $7 \%$ of the population) chose.

\section{(7.1) Representative quantitative surveys}

Questions concerning population religiosity, especially declared religious belief and participation in religious services, are present in the majority of representative socio-

${ }^{26}$ ZDENĚK R. NEŠPOR, Vývoj české sociologie náboženství v mezinárodním a interdisciplinárním kontextu [Evolution of the Czech Sociology of Religion in the International and Interdisciplinary Context], Praha: Scriptorium 2008, passim. 
logical surveys and public opinion polls after 1989. Deeper surveys focusing on this area are much less numerous. The first surveys were conducted under the sponsorship of church bodies, especially the Roman Catholic Church (AUFBRUCH ad.), and soon thereafter, the Czech Republic started participating in international religiosity surveys (ISSP, EVS). In 2006, the only independent Czech sociological survey focusing on religion $(D I N)$ was conducted.

The very first quantitative survey concerning religion, in 1991, sponsored by the Czech Bible Society, was conducted in Czechoslovakia and other post-Communist countries after 1989. It monitored the relationship of the population to (the Christian) religion and the Bible. The survey took the form of a quota sampling on a two thousand respondents and the acquired data are available, as in the case of standard sociological surveys, through the Czech Social Sciences Data Archive at the Institute of Sociology ASCR. Unfortunately, this does not apply to further church-related surveys. This concerns especially the large international survey God after the Communism (AUFBRUCH), conducted by the Roman Catholic sociologist Paul Zulehner, the first portion of which took place in 1997 and the second one in 2007. While table outputs of the first portion were published, ${ }^{27}$ primary data are not available to the public and the survey method is unclear as well. The results of such surveys are usually processed and used only by their direct participants, ${ }^{28}$ who comment on the long-term decline of traditional religiosity and the increase in self-orientation and fatalism.

Such limitations apply also to recent surveys ordered by the Catholic Church, focusing on religiosity of youth (2011) or social perception of the Church (2014), as well as to the case of a (selective) presentation of statistic data concerning the religious life of church corporations. ${ }^{29}$ Whether other churches active in the Czech Republic maintain such statistics or not, such data is not public in most cases and thus it are unavailable for further sociological analyses. ${ }^{30}$

In the 1990s, the Czech Republic accessed international sociological survey programs, some of which deal with religion from a detailed perspective: this means especially the Religion module within the International Social Survey Programme (ISSP), conducted in 1998 (the collection of Czech data took place in 1999) and in 2008, and the European Values Study (EVS), which took place in 1990 (data collection in 1991), 1999, and 2008. In both cases, these are random sample surveys, representative for the whole adult population $(18+)$.

${ }^{27}$ Miklós Tomka and Paul M. Zulehner, Religion und Kirchen in Ost (Mittel) Europa, Ostfildern: Schwabenverlag 2008, passim.

${ }^{28}$ Libor PrudkÝ, Církve a sociální soudržnost v naši zemi [Churches and the Social Cohesion in Our [Czech] Country], Praha: FSV UK 2005, passim; LiBor PRUdKÝ, Inventura hodnot [The Stocktaking of Values], Praha: Academia 2009, passim.

${ }^{29}$ Cf. Radek TichÝ, “Lidé, skupiny a praktiky v české katolické církvi 1997-2005” ["People, Groups, and Practices in the Czech Catholic Church, 1997-2005”], Pražské sociálně vědní studie, SOC-015 (2008), p. 3-33.

${ }^{30}$ Cf. ZDENĚK R. NEŠPOR and ZDENĚK VoJTíšEK, Encyklopedie menších křest'anských církvív České republice [Encyclopedia of Small Christian Churches in the Czech Republic], Praha: Karolinum 2015, passim. 
The ISSP survey is realized in the Czech Republic by the Institute of Sociology ASCR (Dana Hamplová). The data was collected in June and July 1999 by the SC\&C agency $(\mathrm{N}=1224$, return 39\%), and in September 2008 by the Factum Invenio agency $(\mathrm{N}=1512$, return $44 \%)$. The relevant survey module includes the personal, political and religious positions of respondents, with the religious area specializing on personal religious ideas and practices, religiosity of loved ones, social impacts of religiosity, and religious extremism in later surveys. The questionnaire includes a large socio-demographical part. The main notions were published by Hamplováa ${ }^{31}$ and Hamplová and Ǩeháková. ${ }^{32}$

The EVS survey has been conducted in the Czech Republic (or Czechoslovakia in 1991) by the Faculty of Social Studies of Masaryk University in Brno (Ladislav Rabušic). Data was collected in August to October 1991 by the survey department of the Czechoslovak Radio ( $\mathrm{N}=2109)$; in March to May 1999 by SC\&C $(\mathrm{N}=1908)$; and in May to November 2008 again by SC\&C $(\mathrm{N}=1821)$. These surveys were not focused exclusively on the field of religion, although it represented a significant portion of the studied topics, but also on life values, goals and preferences, leisure time, work, and family life. Overall results summarizing all three portions were published by Rabušic and Hamanová. ${ }^{33}$

The only independent Czech religiosity survey Detraditionalization and individualization of religion in the Czech Republic (DIN) was conducted in September and October 2006 by the Institute of Sociology ASCR (Zdeněk R. Nešpor). The survey was a part of a larger study, which will be mentioned later. Data was collected by SC\&C $(\mathrm{N}=1200$, return 53\%), and this survey used a random sample and is representative for the whole adult population. For the purpose of data comparability, it reflected the topics dealt with in the ISSP surveys - Religion, but it included more questions focusing on religious ideas (including nonconformist ones) and practice, relationships among different types of non/belief, and perception of death. Main results were published by Hamplováa ${ }^{34}$ and Lužný and Nešpor. ${ }^{35}$ Recently, there has been a new attempt to resume the DIN survey (Dušan Lužný) at the Palacký University in Olomouc, but the results are not closed nor known as of yet.

${ }^{31}$ Dana Hamplová, Náboženství a nadprirozeno ve společnosti: Mezinárodní srovnání na základě empirického výzkumu ISSP [Religion and the Supernatural in the Society: International Comparison Based on the ISPP Survey], Praha: Sociologický ústav AV ČR 2000, passim; HaMPLOvÁ, Náboženstvív české společnosti na prahu 3. tisíciletí, passim.

32 Dana Hamplová and Blanka Řeháková, Česká religiozita na počátku 3. tisíciletí: Výsledky Mezinárodního programu sociálního výzkumu ISSP 2008 - Náboženství [Czech Religiosity at the Dawning of the Third Millennium: Results of the International Social Survey Program ISPP 2008 Religion], Praha: Sociologický ústav AV ČR 2009, passim.

${ }^{33}$ Ladislav Rabušic and Jana Hamanová, Hodnoty a postoje $v \check{C} R$ 1991-2008 [Values and Attitudes in the Czech Republic, 1991-2008], Brno: Masarykova univerzita 2009, passim.

${ }^{34}$ Dana Hamplová, “Čemu Češi věŕí: dimenze soudobé české religiozity” ["What Do the Czechs Believe in: The Dimensions of Contemporary Czech Religiosity”], Sociologický časopis / Czech Sociological Review 44 (4, 2008), p. 271-294.

${ }^{35}$ DuŠAn LuŽNÝ, ZdenĚK R. NEŠPOR, et al., Náboženství v menšině: Religiozita a spiritualita $v$ současné české společnosti [Religion in Minority: Religiosity and Spirituality in the Contemporary Czech Society], Brno, Praha: Masarykova univerzita, Malvern 2008, passim. 


\section{(7.2) Qualitative sociological and socio-anthropological surveys}

Deeper understanding of different dimensions of the current Czech non/religiosity, consequent social acting and the subjectively felt importance thereof come from qualitative surveys. Their informative value is often restricted by small survey samples within regional, community or topical limits. Many minor surveys have been conducted within qualifying university theses, systematically assigned mainly at the Faculty of Arts of Masaryk University in Brno (Dušan Lužný, David Václavík), the Hussite Theological Faculty of the Charles University (Zdeněk Vojtíšek) and the Faculty of Humanities of the Charles University (Zdeněk R. Nešpor). Diploma and doctoral theses of students usually suffer from failings linked to such types of surveys and only a small portion of these got to be published. Wider, academically funded qualitative sociological and socio-anthropological surveys are much less numerous; in the last twenty years principally three community-type surveys took place (Filipov, Český Kendal (Czech Kendal), Bůh ví proč (God knows why)), as well as alternative religiosity surveys (Zdeněk Vojtíšek) and surveys concerning dying and death (Olga Nešporová).

The first anthropological survey to focus on religion in the scope of a community survey of a smaller town of Moravia, was conducted in 1997-99 by the Faculty of Social Studies of the Charles University in the so-called Filipov (Jiř́ Kabele, Dan Ryšavý). This combined a field stationary survey involving interviews and analysis of source materials. Aside from religiosity it focused on the area of (local) politics, family and social life, work, entrepreneurial activities, and the overall post-revolutionary transformation of society. A specific local feature was a relatively strong evangelical minority, whose congregational life and modifications were the focus of the survey. The main results were published by Ryšavý (1999) and Kabele (2004).

Another community-related survey was Český Kendal, realized within the aforementioned Detraditionalization and individualization of religion in the Czech Republic during 2006-08 as a counterweight and addition to the representative quantitative survey. The survey took place in two mid-scale towns; in Mikulov in South Moravia (Dušan Lužný) and in Česká Lípa in Northern Bohemia (Zdeněk R. Nešpor). It was linked to the religiosity survey methodology used in Kendal, Great Britain. ${ }^{36}$ This involved focusing mainly on the field of religion, dealing with religious and social practices of traditional and alternative believers and their social representation or perception. Given the selection of survey localities, the survey also dealt with social processes in border regions repopulated after WWII or even later. The principal results of the survey including the comparison of religious lives in both localities were published by Lužný and Nešpor. ${ }^{37}$

The last larger-scale socio-anthropological survey God Knows Why was conducted in the Northern Bohemian border region in 2003-2008. The author, Barbora Spalová focused on the functioning of several confessionally defined local communities, their

${ }^{36}$ Cf. Heelas and Woodhead, The Spiritual Revolution, passim.

${ }^{37}$ LuŽNÝ and NEŠPOR, Náboženství v menšině, passim. 
internal power regimes, and memory constructions (this involved two Roman Catholic parishes, a Baptist Union congregation and a Unity of the Brethren congregation). In this survey, the widest spread elements were those of reflective anthropology. Its main focus was understanding the inner motivations of different actors, which, however, renders it less usable for generalization. In summary the results were published by Spalová. ${ }^{38}$

Aside from these surveys, it is necessary to mention long-term monitoring of the so-called religious movements and other alternative forms of religiosity including non-church and non-organized ones done by the scholar of religion Zdeněk Vojtíšek. While Vojtíšek's previous works were influenced by the ideological perspective of an anti-cult approach, the author progressively freed himself from this approach, providing an objective elementary overview of all religious organizations active in the Czech Republic. ${ }^{39}$ His perspective is primarily academic, and as such he concentrates only on monitoring institutions on the "supply side" of the religious marketplace. Such an approach is similar to the project focused on studying and monitoring all protestant congregations ${ }^{40}$ and communities of 27 smaller Christian churches ${ }^{41}$ However, this includes social, socio-geographical, and historical dimensions of the religious institutions' activities; other segments of organized Czech religiosity (Roman Catholic Church, Czechoslovak Hussite Church, non-Christian churches and centers of non-church spirituality) have not been studied yet.

A long-term survey of attitudes (of various segments) of Czech society relating to dying and death including the realization of relevant transitional rites and ideas of a life after death has been conducted by Olga Nešporová since the start of the millennium. The survey combines quantitative and qualitative sociological and socio-anthropological approaches, paying special attention to changing requirements, needs and habits of the dying persons, as well as survivors. The principal results were published by Nešporová. ${ }^{42}$

\section{(7.3) Historical-sociological surveys}

A number of authors believe that the specific form of Czech non/religiosity has its roots at least in the development of Czech attitudes towards religion and churches during the 20th century, if not even earlier. Thus, in the last decades, there has been a rise in historical and historical-sociological monitoring of the field. Here, we will

${ }^{38}$ BARBORA SPALOvá, Bůh ví proč: Studie pamètí a režimů moci v křestanských církvích v severních Čechách [God Knows Why: A Study of Memories and Power Regimes in the Christian Churches of the North Bohemia], Brno: Centrum pro studium demokracie a kultury 2012, passim.

${ }^{39}$ ZDENĚK VoJTíšEK, Encyklopedie náboženských směrů a hnutí v České republice: Náboženství, cirkve, sekty, duchovní společenství [Encyclopedia of Religions and Religious Movements of the Czech Republic: Religions, Churches, Cults, Spiritual Communities], Praha: Portál 2004, passim.

${ }^{40}$ ZDENĚK R. NEŠPOR, Encyklopedie moderních evangelických (a starokatolických) kostelů Čech, Moravy a českého Slezska [The Encyclopedia of the Modern Protestant and Old Catholic Churches of Bohemia, Moravia and Czech Silesia], Praha: Kalich 2009, passim.

${ }^{41}$ NEŠPOR and VoJTíš́EK, Encyklopedie menšich křest'anských církvív České republice, passim.

${ }^{42}$ Olga Nešporová, O smrti a pohřbivání [On Death and Burials], Brno: Centrum pro studium demokracie a kultury 2013, passim. 
however mention only those studies which combine analyses of historic material with the current religiosity status of Czech society.

Nešpor ${ }^{43}$ and Václavík $k^{44}$ published overview works indicating a progressive deviation of a large part of the society from the traditional church-related religiousness and a search for various religious alternatives. The Communist era strengthened the former and hid, while not eliminated, the latter. The scholarly debate significantly benefited from a collection of studies dealing with past and current religiosity from the point of view of (changes of) religious cultures, ${ }^{45}$ or a similar work focusing on older roots of Czech anti-clericalism. ${ }^{46}$ The surveys, which all these works were based on, document the aforementioned notion of continuity (not invariability) of long-term processes of religious evolution within Czech society and the relation of the current state not only to the Communist regime but also to older institutions and tendencies.

The level of elaboration on the institutional history of individual church communities after the 1950s and in the context of their free operation after the fall of the communist regime is unbalanced. While some studies of the socio-culturally created history of the Czech Roman Catholic Church ${ }^{47}$ and some smaller church communities (Seventh-day Adventist Church $^{48}$ ) are available, this is only a handful of cases - it does not apply to any other socially established and politically, socially or culturally influential Czech churches (Czechoslovak Hussite Church and Evangelical Church of Czech Brethren), and even less so to nonconformist and/or non-church or other socially unorganized spiritual communities.

\section{(7.4) Foreign overviews}

Data from publicly available quantitative surveys of Czech religiosity is available for the international research community via the Leibniz Institute for the Social Sciences (GESIS) data archive or through the Czech Social Sciences Data Archive at the Institute of Sociology ASCR. Almost all the aforementioned studies analysing and interpreting sociological or historical data concerning Czech religiosity were published only in Czech, thus being not directly available for foreign researchers. This does not

${ }^{43}$ ZdenĚK R. NešPor, et al., Náboženství v 19. století: Nejcírkevnější století, nebo období zrodu českého ateismu? [Religion in the 19th Century: Century of the Churches or the Birth of Czech Atheism?], Praha: Scriptorium 2010, passim; NEŠPOR, Př́lišs slábi ve víre, passim.

${ }^{44}$ VÁClavík, Náboženství a moderní česká společnost, passim.

${ }^{45}$ Miloš HavelKa, et al., Vira, kultura a společnost: Náboženskékulturyv českých zemích 19. a 20. století [Belief, Culture, and Society: Religious Cultures in the Czech Lands of the 19th and 20th Century], Červený Kostelec: P. Mervart 2012, passim.

${ }^{46}$ Stanislav Balík, Lukáš Fasora, Jiří Hanuš, and Marek Vlha, Český antiklerikalismus: Zdroje, témata a podoba českého antiklerikalismu v letech 1848-1938 [Czech Anticlericalism: Sources, Topics, and Shape of Czech Anticlericalism, 1848-1938], Praha: Argo 2015, passim.

47 Stanislav BALíK and JiŘí Hanuš, Katolická církev v Československu 1945-1989 [The Catholic Church in Czechoslovakia, 1945-1989], Brno: Centrum pro studium demokracie a kultury 2007, passim.

${ }^{48}$ Jiǩí Piškula, Dějiny Církve adventistů sedmého dne v Čechách, na Moravě a ve Slezsku [History of the Church of the Seventh Day Adventists in Bohemia, Moravia and Silesia], Praha: Advent, Orion 2009, passim. 
mean that there are no overview or even analytical studies published in internationally comprehensible languages.

The most accessible manual of modern Czech church history compiled according to the development in particular churches was published by Schulze Wessel and Zückert. ${ }^{49}$ An overview of data concerning religious confession based on population censuses and sociological surveys for the whole of the 20th century was published by Nešpor. ${ }^{50}$ Sociological analyses of the DIN and ISSP surveys - Religion were published by Hamplová and Nešpor ${ }^{51}$ and by Vido, Václavík and Paleček. ${ }^{52}$ Some results of surveys concerning dying and death ${ }^{53}$ or socio-geographical surveys of traditional and emerging holy places in the landscape ${ }^{54}$ are also available.

\section{Acknowledgements}

This text was created as a result of The Future of Religious Faith from Central European Perspective project funded by the Templeton Foundation (www.budoucnost nabozenstvi.cz).

\section{References}

BALÍK, StAnislav, and JiŘí Hanuš, Katolická církev v Československu 1945-1989 [The Catholic Church in Czechoslovakia, 1945-1989], Brno: Centrum pro studium demokracie a kultury 2007, 399 p.

BAlík, Stanislav, Lukáš Fasora, JiŘí Hanuš, and Marek Vlha, Český antiklerikalismus: Zdroje, témata a podoba českého antiklerikalismu v letech 1848-1938 [Czech Anticlericalism: Sources, Topics, and Shape of Czech Anticlericalism, 1848-1938], Praha: Argo 2015, 490 p.

Froese, Paul, "Secular Czechs and Devout Slovaks: Explaining Religious Differences", Review of Religious Research 46 (3, 2005), p. 269-83.

Froese, Paul, and Steven Pfaff, "Explaining the Religious Anomaly: A Historical Analysis of Secularization in Eastern Germany”, Journal for the Scientific Study of Religion 44 (4, 2005), p. 397-422.

${ }^{49}$ Martin Schulze Wessel and Martin Zückert (eds.), Handbuch der Religions- und Kirchengeschichte der böhmischen Länder und Tschechiens im 20. Jahrhundert, München: Oldenbourg 2009, passim.

${ }^{50}$ ZDENĚK R. NešPor, “Der Wandel der tschechischen (Nicht-)Religiosität im 20. Jahrhundert im Lichte soziologischer Forschungen." Historisches Jahrbuch 129 (2009), p. 501-532.

${ }^{51}$ Hamplová and NešPor, "Invisible Religion in a 'Non-believing' Country”, p. 581-597.

${ }^{52}$ Roman Vido, David Václavík, and Antonín Paleček, "Czech Republic: The Promised Land for Atheists?" in Roberto Cipriani and Franco Garelli (eds.), Sociology of Atheism. Leiden: Brill 2016, p. 201-232.

53 Olga Nešporová, "Believer Perspectives on Death and Funeral Practices in a Non-believing Country”, Sociologický časopis / Czech Sociological Review 43 (6, 2007), p. 1175-1193.

${ }^{54}$ Tomáš HavlíčEK and Martina Hupková, "Sacred Structures in the Landscape: The Case of Rural Czechia”, Scottish Geographical Journal 129 (2, 2013), p. 100-121; OLGA NEŠPOROVÁ, "Everprivate Grief in Public Space: Roadside Memorials in the Czech Republic," in MARIUs Rotar and Adriana Teodorescu (eds.), Dying and Death in 18th-21st Century Europe, Newcastle upon Tyne: Cambridge Scholars Publishing 2011, p. 331-350. 
Greeley, ANDrew M., Religion in Europe at the End of the Second Millennium: A Sociological Profile, New Brunswick: Transaction Publishers 2003, 252 p.

HAMPlová, DANA, Náboženství a nadprirozeno ve společnosti: Mezinárodní srovnání na základě empirického výzkumu ISSP [Religion and the Supernatural in the Society: International Comparison Based on the ISPP Survey], Praha: Sociologický ústav AV ČR 2000, 60 p.

Hamplová, Dana, “Čemu Češi věří: dimenze soudobé české religiozity” ["What Do the Czechs Believe in: The Dimensions of Contemporary Czech Religiosity”], Sociologický časopis / Czech Sociological Review 44 (4, 2008), p. 271-294.

Hamplová, Dana, Náboženstvív české společnosti na prahu 3. tisíciletí [Religion and the Czech Society on the Threshold of the Third Millennium], Praha: Karolinum 2013, 151 p.

HAMPlová, DANA, and ZdenĚK R. NeŠPor, "Invisible Religion in a 'Non-believing' Country: The Case of the Czech Republic”, Social Compass 56 (4, 2009), p. 581-597.

Hamplová, Dana, and Blanka ŘEHÁKová, Česká religiozita na počátku 3. tisíciletí: Výsledky Mezinárodního programu sociálního výzkumu ISSP 2008 - Náboženství [Czech Religiosity at the Dawning of the Third Millennium: Results of the International Social Survey Program ISPP 2008 - Religion], Praha: Sociologický ústav AV ČR 2009, 139 p.

Havelka, Miloš, et al., Víra, kultura a společnost: Náboženské kultury v českých zemích 19. a 20. století [Belief, Culture, and Society: Religious Cultures in the Czech Lands of the 19th and 20th Century], Červený Kostelec: P. Mervart 2012, 520 p.

Havlíčex, Tomáš, and Martina Hupková, "Sacred Structures in the Landscape: The Case of Rural Czechia”, Scottish Geographical Journal 129 (2, 2013), p. 100-121.

Heelas, Paul, Linda Woodhead et al., The Spiritual Revolution: Why Religion Is Giving Way to Spirituality, Oxford: Blackwell 2005, 224 p.

KABELE, JIŘí, "Filipovští evangelíci a svět před koncem druhého tisíciletí." [“The Protestants of Filipov and the World at the End of the Second Millennium"], in JoseF KANDERT (ed.), Jihomoravský venkov po socialismu. Filipovsko na konci devadesátých let 20. století (Filipov III.), Praha: Matfyz Press 2004, p. 20-57.

LuŽNÝ, Dušan, and Jolana Navrátilová, "Religion and Secularisation in the Czech Republic”, Czech Sociological Review 9 (1, 2001), p. 85-98.

LUŽNÝ, DUŠAN, ZDENĚK R. NEŠPOR, et al., Náboženství v menšině: Religiozita a spiritualita $v$ současné české společnosti [Religion in Minority: Religiosity and Spirituality in the Contemporary Czech Society], Brno, Praha: Masarykova univerzita, Malvern 2008, $206 \mathrm{p}$.

McGrath, Alister E., The Future of Christianity, Oxford: Oxford University Press 2002, $184 \mathrm{p}$.

MülleR, OlAF, “Secularization, Individualization, or (Re)vitalization?: The State and Development of Churchliness and Religiosity in Post-Communist Central and Eastern Europe", Religion and Society in Central and Eastern Europe 4 (1, 2011), p. 21-37.

NEŠPOR, ZDENĚK R., Vývoj české sociologie náboženstvív mezinárodním a interdisciplinárnim kontextu [Evolution of the Czech Sociology of Religion in the International and Interdisciplinary Context], Praha: Scriptorium 2008, 429 p.

NEŠPOR, ZDENĚK R., Encyklopedie moderních evangelických (a starokatolických) kostelì Čech, Moravy a českého Slezska [The Encyclopedia of the Modern Protestant and Old Catholic Churches of Bohemia, Moravia and Czech Silesia], Praha: Kalich 2009, 561 p.

NEŠPoR, ZDENĚK R., "Der Wandel der tschechischen (Nicht-)Religiosität im 20. Jahrhundert im Lichte soziologischer Forschungen”, Historisches Jahrbuch 129 (2009), p. 501-532. 
NeŠPor, ZdenĚK R., et al., Náboženstvív 19. století: Nejcírkevnějši století, nebo období zrodu českého ateismu? [Religion in the 19th Century: Century of the Churches or the Birth of Czech Atheism?], Praha: Scriptorium 2010, 324 p.

NeŠPOR, ZdENĚK R., Př́lišs slábi ve víre: Česká ne/religiozita v evropském kontextu [Too Weak in Faith: Czech Non/Religiosity in the European Context], Praha: Kalich 2010, 214 p.

NEŠPOR, ZDENĚK R., and ZDENĚK VoJTíšEK, Encyklopedie menšich křest'anských církví $v$ České republice [Encyclopedia of Small Christian Churches in the Czech Republic], Praha: Karolinum 2015, 655 p.

NešPorová, Olga, "Believer Perspectives on Death and Funeral Practices in a Nonbelieving Country”, Sociologický časopis / Czech Sociological Review 43 (6, 2007), p. $1175-1193$.

NeŠPorová, Olga, and ZdenĚK R. Nešpor, "Religion: An Unsolved Problem for the Modern Czech Nation”, Sociologický časopis / Czech Sociological Review 45 (6, 2009), p. 1215-37.

NeŠPorová, Olga, "Everprivate Grief in Public Space: Roadside Memorials in the Czech Republic," in Marius Rotar and Adriana Teodorescu (eds.), Dying and Death in 18th-21st Century Europe, Newcastle upon Tyne: Cambridge Scholars Publishing 2011, p. 331-350.

Nešporová, Olga, O smrti a pohřbivání [On Death and Burials], Brno: Centrum pro studium demokracie a kultury 2013, $351 \mathrm{p}$.

PIŠKula, Jiří, Dějiny Církve adventistů sedmého dne v Čechách, na Moravě a ve Slezsku [History of the Church of the Seventh Day Adventists in Bohemia, Moravia and Silesia], Praha: Advent, Orion 2009, 202 p.

Pollack, Detlef, “The Change in Religion and Church in Eastern Germany after 1989:

A Research Note”, Sociology of Religion 63 (3, 2002), p. 373-87.

Protero, Stephen, Religious Literacy, New York: HarperOne 2008, 371 p.

PRUdKÝ, Libor, Církve a sociální soudržnost v naši zemi [Churches and the Social Cohesion in Our [Czech] Country], Praha: FSV UK 2005, 89 p.

PRUDKÝ, Libor, Inventura hodnot [The Stocktaking of Values], Praha: Academia 2009, $341 \mathrm{p}$.

RABUŠIC, LADISLAV, and JANA HAMANOvÁ, Hodnoty a postoje $v \check{C} R$ 1991-2008 [Values and Attitudes in the Czech Republic, 1991-2008], Brno: Masarykova univerzita 2009, 324 p.

Remmel, Atкo, "Ambiguous Atheism: The Impact of Political Changes on the Meaning and Reception of Atheism in Estonia", in Roberto Cipriani and Franco GARELli (eds.), Sociology of Atheism, Leiden: Brill 2016, p. 233-251.

RYŠAVÝ, DAN, “'Berani“ - sociální historie evangelického sboru” [“'Berani” - A Social History of a Protestant Congregation"], in Filipov II: Informatoria katedry sociologie ISS FSV UK v Praze, Praha: FSV UK 1999, p. 187-202.

Schulze Wessel, Martin, and Martin Zückert (eds.), Handbuch der Religions- und Kirchengeschichte der böhmischen Länder und Tschechiens im 20. Jahrhundert, München: Oldenbourg 2009, 942 p.

Smith, Tом W., "Beliefs about God across Time and Countries", in Insa Bechert and Markus QuAndT (eds.), ISSP Data Report: Religious Attitudes and Religious Change, Köln: GESIS 2013, p. 13-28.

SPAlOvá, BARBora, Bůh víproč: Studie pamètí a režimů moci v krest'anských církvích $v$ severnich Čechách [God Knows Why: A Study of Memories and Power Regimes in the Christian Churches of the North Bohemia], Brno: Centrum pro studium demokracie a kultury 2012, 417 p. 
TichÝ, RADEK, “Lidé, skupiny a praktiky v české katolické církvi 1997-2005” [“People, Groups, and Practices in the Czech Catholic Church, 1997-2005”], Pražské sociálně vědnístudie, SOC-015 (2008), p. 3-33.

Tomka, Miklós, and Paul M. Zulehner, Religion und Kirchen in Ost (Mittel) Europa, Ostfildern: Schwabenverlag 2008, 208 p.

VÁClavík, David, Náboženství a moderní česká společnost [Religion and the Modern Czech Society], Praha: Grada 2010, 243 p.

VÁNĚ, JAN, "Výzkumy věnující se podobám religiozity v České republice po roce 1989" "Surveys of the Different Religiosities in the Czech Republic after 1989"], in JindřICH KREJČí and YANA LeontiYeva (eds.), Cesty $k$ datüm: Zdroje a management sociálněvědních dat v České republice, Praha: Sociologické nakladatelství 2012, p. 354376.

VÁNĚ, Jan, and MARTina ŠTípková, “The National Religious Environment and the Orthodoxy of Christian Beliefs: A Comparison of Austria, the Czech Republic and Slovakia”, Sociologický časopis / Czech Sociological Review 49 (3, 2013), p. 403-25.

Vido, Roman, David Václavík, and Antonín Palečex, "Czech Republic: The Promised Land for Atheists?” in Roberto Cipriani and Franco Garelli (eds.), Sociology of Atheism. Leiden: Brill 2016, p. 201-232.

Voas, David, "The Rise and Fall of Fuzzy Fidelity in Europe", European Sociological Review 25 (2, 2009), p. 155-68.

VoJTíšEK, ZDENĚK, Encyklopedie náboženských směrů a hnutív České republice: Náboženství, církve, sekty, duchovní společenství [Encyclopedia of Religions and Religious Movements of the Czech Republic: Religions, Churches, Cults, Spiritual Communities], Praha: Portál 2004, 462 p.

Wohlrab-Sahr, Monika, “'Forced' Secularity?: On the Appropriation of Repressive Secularization", Religion and Society in Central and Eastern Europe, 4 (1, 2011), p. 63-77.

ZRINŠČAK, SinišA, "Generations and Atheism: Patterns of Response to Communist Rule Among Different Generations and Countries”, Social Compass 51 (2, 2004), p. 221-34. 